\title{
Historical Geographies of the Future: Airships and the Making of Imperial Atmospheres
}

\author{
Martin Mahony \\ School of Environmental Sciences, University of East Anglia
}

\begin{abstract}
This paper explores the elemental encounters and imaginative geographies of empire in order to develop a new means of engaging with the historical geographies of the future. Futures have recently become an important topic of historical and cultural inquiry, and historical geographers have an important role to play in understanding the place of the future in the past, and in interrogating the role of posited futures in shaping action in historical presents. Drawing on literature from science \& technology studies, a framework is developed for engaging with the material and imaginative geographies which coalesce around practices of imagination, expectation and prediction. This framework is then used to reconstruct efforts to develop airship travel in the British Empire in the 1920s and '30s. At a moment of imperial anxiety, airships were hoped to tie the empire together by conveying bodies, capital and military capacity between its furthest points. Confident projections of the colonisation of global airspace were nonetheless undermined by material encounters with a vibrant, often unpredictable atmospheric environment. The paper aims to spur renewed work on the historical geographies of the future, while also contributing to debates on the cultural and political geographies of the atmosphere and of atmospheric knowledgemaking.
\end{abstract}

Keywords: future; atmosphere; technology; empire; mobility

\section{Historical Geographies of The Future}

As the onset of the Anthropocene telescopes geological time into a politically febrile present, and as environmental dystopias and technological utopias jostle for authority as horizons of collective action, 'the future' has become an increasingly prominent object of political contestation, technoscientific construction, and cultural critique. Geographers have joined a growing band of historians, sociologists, philosophers, and students of culture and media in examining the construction of authoritative or influential visions of possible futures, and in interrogating the work performed by such visions in the organisation and contestation of collective life (e.g. Eshun 2003; Koselleck 2004; de Goede and Randalls 2009; Andersson 2012; Augé 2014; Tutton 2016). Geographers have examined the codification and performance of futures within the anticipatory mechanics of liberal government (Amoore 2009; Anderson 2010), the politics of expertise in the construction of knowable futures (Rickards et al. 2014; Lave 
2015), and the effects of social marginalisation in the definition of who gets to imagine and define futures (Derickson and MacKinnon 2015; Baldwin 2016). A recent special issue of the Annals of the American Association of Geographers urged the discipline to re-engage with both the politics and the creative praxis of imagining alternative futures (Braun 2015). While this is partly motivated by the realisation that, in the Anthropocene, the past no longer furnishes useful analogies for the future, historical geography still faces two urgent tasks: examining how historical processes, such as those of colonialism and capital formation, (dis)empower different social groups to define and enact alternative futures in the present (Collard et al. 2015); and examining the long history of 'the future' as an imagined, constructed object around which various projects of knowledge-making and world-making have been organised.

This article aims to develop new pathways for the cultivation of historical geographies of the future, focusing in this instance on the latter concern with the future as an historical object. Building on recent work on the material, elemental and affective geographies of air and atmosphere (e.g. Adey et al. 2013; McCormack 2018), I make the case for the atmosphere as a useful space through which to reconstruct historical geographies of the future, focusing in this instance on efforts to remake British imperialism through the development of airship technology during the 1920s. The airship itself is in many ways an icon of futures-past, featuring prominently in, for example, early $20^{\text {th }}$ century visions of international techno-authoritarian government (e.g. Kipling 1905), and more recently in the retro-futurism of steampunk (Davidson 2012). It is an ideal vehicle then in which to join a growing band of historians and, increasingly, historical geographers in examining the place of the future in the past.

Recent geographical work has offered new appreciations of the power of future imaginaries in the remaking of urban, national and imperial spaces (Gilbert and Driver 2000; Bell 2007; Gilbert and Lambert 2010; Krige and Wang 2015), as well as new disciplinary histories (Heffernan 1999). The intertwining of possible futures and alternative histories has been the subject of important interventions around counterfactual methods in geography, as a means of jointly comprehending spatial and historical contingency (Gilbert and Lambert 2010; Palmer 2014). Beyond the discipline, a burgeoning interdisciplinary literature has emerged on the history of prediction, foreknowledge and imagination in the organisation of science, government, commerce and collective life (e.g. Andersson and Rindzevičiūte 2015; Jasanoff and Kim 2015). This literature has developed in various levels of dialogue with the history of utopian imaginings (e.g. Jameson 2005), although Andersson $(2012,1414)$ has recently called for "a new field of historical inquiry, 
one that will move away from the cultural history of utopias and images of the future that historians have studied to date, and focus on the role of prediction in structuring action and actors on the national, transnational, and global levels". While this is a vital move, I will argue in this article that we shouldn't throw out the imaginative baby with the utopian bathwater.

Separating our study of the utopian imagination from the study of the social role of anticipation and prediction would be a mistake. Historical geography as a field has been particularly adept at working with the co-production of the imaginative, the technical and the material, most prominently perhaps through the reconstruction of historically-situated imaginative geographies, and of the evolution of the 'geographical imagination' (Daniels 2011). A fuller historical geography of the future can disaggregate different modes of futuring, while also attending closely to their mutual shaping of each other. In this article, I propose that examining imagination, expectation and prediction as distinct and yet interacting modes of futuring or future-making can offer a firmer grasp on the work performed by claims upon the future in the organisation of life in various historical presents. These modes resonate with Anderson's "practices" of anticipation, by which "futures are made present in affects, epistemic objects and materialities" (Anderson 2010, 779). Imagination, expectation and prediction are all, in part, cognitive practices, ranging from the banal and the technical to the creative and fanciful, but they all work through sociocultural and material processes and practices, and summon into being a range of both material and imaginative geographies. In the following section I examine a range of conceptual resources which can inform this renewed geographical engagement with futures, both past and present.

\section{Imagination, Expectation, Prediction}

In this section I discuss treatments of spatiality in existing literatures on imagination, expectation and prediction, and explore how geographers are already developing new ways of interrogating the spaces and places of future-making. Building on important work on how threats to existing orders and lifeworlds are anticipated and governed through present geographies (e.g. Anderson and Adey 2012), my emphasis here will be on emerging engagements with efforts to make new worlds through the mobilisation of imagination, expectation and prediction. To begin with, I explore the extent to which the notion of 'sociotechnical imaginaries' can inform a renewed understanding of the geographical imagination. 


\section{Socio-technical imaginaries and the horizons of possible worlds}

The concept of socio-technical imaginaries has recently emerged in science and technology studies (STS), and describes "collectively held, institutionally stabilized, and publicly performed visions of desirable futures, animated by shared understandings of forms of social life and social order attainable through, and supportive of, advances in science and technology" (Jasanoff 2015, 4). The concept comes from a strand of STS work which is not concerned so much with the material and social practices of the laboratory (Latour and Woolgar 1979), but more with how science and technology get bound up with projects of world-making beyond laboratory walls (see Jasanoff 2004). It's a strand of work which sees science and social order as joint products of processes of co-production, emphasising the place of the normative and the aspirational in processes of technoscientific change, while also stressing the role of science and technology in producing social collectives in the present (cf. Taylor 2002), and visions of desirable forms of social order in the future.

Socio-technical imaginaries are socially durable visions of socio-technical futures. They lie in between utopia and the predictable near-future, and tell of individual, vanguard visions which, through the mobilisation of various cultural and symbolic resources, come to be collectively held and to exercise agency in the organisation of collective life. The concept draws attention to "how, through the imaginative work of varied social actors, science \& technology become enmeshed in performing and producing diverse visions of the collective good, at expanding scales of governance from communities to nation-states to the planet" (Jasanoff 2015, 11). Recent work in this area has examined comparative imaginaries of the relationship between the state and nuclear power (Jasanoff and Kim 2009), and global health governance (Lakoff 2015). The concept has more recently been mobilised to understand how socio-technical innovations travel, in order to grasp how dominant conceptions of social and technical change are transformed in encounters with 'local' commitments and cultures (e.g. Pfotenhauer and Jasanoff 2017). The literature on socio-technical imaginaries bears a commitment to uncovering the "topographies of power" within which science and technology are entangled, often pitched against what is seen as the flatter ontologies of actor-network theory accounts of the heterogeneous engineering of matter and society (Jasanoff 2015,18$)$. However, spatial order is often conflated here with social order, and articulated in relation to hegemonic state power. Counter-hegemonic imaginaries have not yet received the same level of analytical attention, and the critical potential of movements such as Afrofuturism (Eshun 2003; Yaszek 2006) to centre 
the imagination as both object of inquiry and site of intervention has not yet been realised in STS. Nonetheless, the concept of socio-technical imaginary is being increasingly employed to interrogate the scalar politics of science and technology, echoing geographical work on scale as an effect of practice and ideological contestation (Legg 2009): “imaginaries not only help reconfigure actors' sense of the possible spaces of action but also their sense of the rightness of action, at scales ranging from locality to nation...to continent... and to the planet itself' (Jasanoff 2015, 23). Although beyond the scope of this paper, more work is required to explore the role of imaginaries in the scalar politics of counter-hegemonic or decolonial articulations of sociotechnical futures.

Work on socio-technical imaginaries may provide a useful corollary to work on the geographical imagination. Daniels $(2011,183)$ notes that the concept of the geographical imagination "varies in scope", from particular techniques of fashioning representations of space, to more overarching "modes of comprehension and experience...encompassing the condition of both the known world and the horizons of possible worlds". These modes of comprehension have been situated within the historical development of geography as a discipline, formatting, like Kuhnian paradigms, the ways in which space and place, as general or specific, have been constructed and interpreted. More broadly, the geographical imagination stands for a more distributed mode of comprehending space and the characteristics of place - most obviously perhaps the popular and scientific construction of 'the tropics' as a place of pestilence and moral degeneracy which shaped both knowledge-making and world-making projects at the height of European imperialism (Driver 2004). Work on the geographical imagination has not yet connected fully with work on the geographies of anticipation, with time losing out to space as the key dimension. Yet Daniels' reference to the "horizons of possible worlds" hints at a latent potential to couple work on the spatial imaginaries of empire-builders, scientists and geographers with work which engages more closely with the power of future imaginaries to shape action in historical presents. Leaning on the concept of socio-technical imaginaries can help re-cast the place of the future in the organisation and contestation of present geographies, while also offering a new means of placing science and technology within the production, circulation and enactment of powerful imaginaries, potentially finessing our grasp of the relationship between science, technology and geopolitics (Butler 2001). The notion of socio-technical imaginaries emphasises that spatial imaginations "preexist and channel the spread of science and technology, instead of only vice versa" (Jasanoff 2015, 22); imaginaries have agency in the emergence and 
expansion of local and regional cultures of scientific knowledge-making, as well as being themselves products of the situated making of (anticipatory) knowledge (cf. Livingstone 2003; Naylor 2010).

\section{Spaces of expectation}

If 'imagination' here denotes big-picture constructions of worldly futures, "attainable" through, and supportive of, certain strategies of physical and social engineering (Jasanoff 2015, 4), then that attainment is achieved through practices of "engineering expectancy" (McCormack 2008, 423). An important strand of work on the sociology of expectations has developed from studies of socio-technical innovation (Tutton 2016). While much work on socio-technical imaginaries operates on the level of the nation-state, sociologists of expectations take individual projects of technological innovation as their scale of analysis. They examine more closely the material and discursive practices by which expectations of change and promissory regimes are constructed and contested. Four key themes have emerged from such work: the constitutive and performative role of expectations in the social negotiation of technological innovation; the temporal patterning of regimes of expectation, expressed for example in cycles of 'hype' and 'disappointment'; the materiality and embodiment of expectations, in people, texts, artefacts and actions; and the 'socio-spatial variability' of expectations (Borup et al. 2006, 289-293). On the latter, Porter and Randalls $(2014,204)$ attempt to thicken an "impoverished sense of space and scale" sociological studies of expectations; to go beyond mapping the spatiality of expectations in simple terms of circulation and social variation. Building on Milne (2012), a fuller geography of expectations needs to examine the places of future production, the scales of future enactments, the embedding of imagined futures in the materialities of present geographies, and the agency of imagined places in transforming those geographies (Porter and Randalls 2014: 204; also Lehman 2014; Dressler 2017). There are important echoes here of Anderson's work on how "geographies are made and lived in the name of preempting, preparing for, or preventing threats to liberaldemocratic life" (Anderson 2010, 777), and of work which interrogates how strategies of expectation and anticipation, as related to threats such as nuclear war, were written into architectural forms and biopolitical practices (e.g. Klinke 2017). However, geographers could profitably supplement this engagement with the logics of threat with a fuller engagement with the promissory regimes through which forms of capitalist and liberal-democratic life are reproduced, extended, and spatially fixed through the rhetoric and practice of 'innovation'. 
With imagination here referring to the hoped-for end points of social and technical change, expectation refers to the belief in the causal relationships and sequences that are assumed to link the present with an imagined future. These causal relationships may be unquantifiable according to historically-situated norms of reliable scientific prediction, and may refer, for example, to assumed relationships between the public performance of 'future' technologies and the generation of public acceptance or expectancy, to assumed pathways of technological innovation, where one development leads linearly to another, or to the performance of machines in imperfectly known future conditions. Expectation may often strive towards predictability, but my emphasis here will be on the paradoxical relationship between the indeterminacy of assumed relationships, and the powerful performativity of expectations in shaping action in the present (Tutton 2016).

\section{Politics of prediction}

Rather than the links between present actions and future outcomes, 'prediction' here refers more explicitly to claims made about the evolution of certain systems over time and space: for example, a prediction of the weather over the next six or twelve hours. These systems may exist and behave partially or completely independently of a technology around which expectations are being fashioned. Nonetheless, historians of science such as Anderson (2005) and Pietruska (2017) have shown prediction to be a culturally-situated set of practices shaped by power relationships and often interminable contestations over authority. Pietruska (2017) has recently explored the centrality of predictive practices in efforts to re-make American capitalism in the late $19^{\text {th }}$ century, albeit not resulting in the successful extension of a future-proof administrative rationalism, but in a widespread acceptance of uncertainty as an inevitable facet of social, economic and physical systems. Looking to more recent cases, geographical work has highlighted the material circulation of distinctive predictive practices (Jankovic 2004; Mahony and Hulme 2012), and the constitutive effects of hegemonic modes of prediction in the spatial ordering of, for example, climate change politics (O’Lear 2016; see also Taddei 2013). As Eshun (2003, 289) observes, "power now operates predictively". Predictions render "complex future geographies actionable through the numericalization of a reality to come", generating authoritative numbers and visions "that may thereafter circulate, be reflected on and take on an affective charge" (Anderson 2010, 784). Similarly to how the literature on expectations would benefit from a renewed geographical orientation, work on the history of prediction would be enhanced by supplementing an interest in circulation and spatial variation with attention to places of 
predictive knowledge-making, and the embeddedness and agency of predicted spatialities within present geographies.

While predictions may refer to systems assumed to be independent or external to the sociotechnical systems which are the subject of hopeful imaginings and expectations, the practices and politics of prediction, I'll suggest, are profoundly shaped by the imaginative and expectant contexts within which they are produced and put to work. This triad of imagination, expectation and prediction can enrich our grasp of the historical geographies of the future, encouraging us to attend to the mutual shaping of these three modes of futuring, and to the imagined and material geographies through which they work. In the rest of this article, I use this conceptual triad to reconstruct the historical geographies of British imperial airshipping in the 1920s and '30s.

\section{Atmospheres of the Imperial Future}

The atmosphere has long figured as a space for the projection of hopeful or fearful futures, as a space ripe for technological conquest or as an unknowable 'atopia' possessed of a threatening, inhuman alterity (Carroll 2015). The surveillance of the atmosphere's physical and chemical properties predates recent concerns about global climate change, and has always been marked by an intersection of new forms of atmospheric vision, mobility, and new articulations of responsible conduct and state power (Baker forthcoming; Whitehead 2011). Likewise, emerging atmospheric governmentalities have articulated new geographies of surveillance, policing and violence (Gregory 2011; Adey et al. 2013; Shaw 2016). This change in the political and cultural geographies of the atmosphere, from unknowable atopia to sphere of technological domination, has been driven not just by new techniques of scientific surveillance, but by the capacity of human bodies and technologies to both traverse and inhabit atmospheric space (Adey 2010). Yet aviation, military or civilian, does not take place in an empty 'airspace' through which power can be projected unimpeded (Lin 2016), but works instead through a set of relations with the material processes of the atmosphere (Adams-Hutcheson 2017) - those nonhuman forces which can freely "undo, arrest, deviate, or destroy the human systems of global circulation with which they become associated" (Carroll 2015, 7); forces which aerostatic bodies like balloons and airships are particularly susceptible to, and expressive of (McCormack 2018). But while the elemental geographies of air have increasingly been of interest to scholars working in new materialist traditions (see Adey 2015), the spokespeople of these processes and relations, and particularly of their possible futures (meteorologists, for example), have nonetheless been largely 
absent from work which seeks to write social relations into matter (Barry 2015). Emerging work on the historical geographies of meteorological and climatological science is yielding important insights into the embedding of those fields into imperial projects, and their role in constructing the atmosphere as navigable airspace (Henry 2014; Mahony 2016). In interwar Britain, air links with Europe were intensifying and hopes abounded that the Empire could be tied together by a new network of aeroplanes and airships (Pirie 2009). Imaginations of a new imperial order intersected with expectations of technological change, and with the capacities of physical scientists and engineers to accurately predict the behaviour of an atmosphere whose chaotic dynamism was only starting to come into view (Fleming 2016). British airshipping therefore illustrate the intersections of imagination, expectation and prediction in the making and unmaking of imperial futures. The atmosphere figured here as a space where imperial futures were projected, climatic anxieties negotiated, and the chaos of turbulent matter fatefully reckoned with by meteorological minds and piloting bodies.

In the period immediately following World War I the airship was a paradoxical figure in British atmospheric politics. On the one hand, the bombing of British towns and cities by German Zeppelins built on earlier, spectral 'airship scares' (Adey 2010, 54-6) to create a paranoia of violated territorial sovereignty and of an invisible, ever-present threat. However, Freedman argues that come the end of the war, the Zeppelin threat had become an increasingly banal part of urban life on the home front, their relative ineffectiveness and vulnerability to new modes of attack tarnishing their aura of other-worldly invincibility (Freedman 2004). Nonetheless, wouldbe imperial airshippers faced a difficult task to convince a sceptical government, military and public about the potential of dirigibles in the wider post-war task of remaking and repurposing empire.

Socio-technical imaginaries have vanguards before they become collectively held (Hilgartner 2015), and in this case the most significant vanguard figure was Charles Dennistoun Burney. A naval engineer who went on to work for the Vickers Company following World War I, Burney entered Parliament in 1922 as the Conservative MP for Uxbridge. In that same year he put forward a scheme for the development of airship communications throughout the Empire, proposing the building of 6 airships by Vickers, with government subsidy, to serve the expected new routes which would tie together England with India and the Dominions. His presence in Parliament allowed him to circulate around the committee rooms of Whitehall where, despite frequently aired technical and financial reservations, the vision of an empire tied together by 
roving airships gained cross-party support. Frequent letters to the press commenting on government deliberations, and regular participation in parliamentary debates, kept the pressure on ministers. Fellow Conservatives were particularly drawn to the scheme, with its combination of "imperial vision and favourable business provisions" (Duggan and Meyer 2001, 85), as were companies such as Shell Oil, one of whose engineers was working on a lightweight airship engine, and who stood to benefit from an expected boom in demand for aviation fuel (Swinfield 2012, 94).

Burney was a self-described progressive imperialist, concerned with the economic, cultural and technical unity of empire. He outlined his thinking in a 1929 book, The World, the Air and the Future, in which he fleshed out a philosophy of airship imperialism. "By means of air travel and air travel alone", Burney argued, "can the British Empire conquer her great enemies - Time and Space” (Burney 1929, 22). Airships could bolster Imperial defence, offering long-distance reconnaissance and new modes of attack. But the main benefits, Burney suggested, were to be economic and cultural. The British Empire stood as the only viable economic rival to an ascendant US, but the Empire's economic development was hampered by the great distances between its main economic nodes. If these nodes could be tied together by a mode of transport that could greatly expedite the circulation of people, ideas, goods and capital, then the resources of Empire could be more productively turned into trade and profit. Burney's thinking chimed with contemporary aviation thinkers like Leo Amery, whose ideas on the links between geography, air power and empire echo through the pages of Burney's writings (see Epstein 2010). But for the latter, imperial development was also hampered by a lack of a widespread sense of cultural unity - "our Imperial consciousness is not yet fully awake”, Burney explained; the Empire as a "spiritual organism" had not yet achieved the religious devotion of the "Imperium Romanum". The airship stood ready to build both commercial and cultural affinity, shrinking the "Imperial globe" to "less than a quarter of its present size" (ibid, 19, 40). Ever the engineer, Burney argued that if the "far-flung Commonwealth is to function effectively as an Imperial entity, its member states must be welded together into a physical unity" (ibid, 21), to create what he called a "British cosmopolis" (ibid, 44).

Alongside this imaginary of imperial development shaped by new geographies of aerial mobility, Burney also proffered a more foundational theory of technology, history, and the future, positing what he called an "historico-metaphysical parallel between the development of communications and the psychological evolution of organised society" (Burney 1929, 169). The air, while 
conducive to the projection of imperial power, was also to be the natural domain of internationalism. In this period internationalism encompassed a variety of utopian ideals of international cooperation, post-national organisation, and peace-making, ranging across liberal cosmopolitanism to communism, and informing organisations like the League of Nations, as well as emerging anti-colonial movements (Goswami et al. 2012; Hodder et al. 2015). Burney was quick to point out that he was following neither "the absurdities of Bolshevism" nor the "idle speculations" of utopian theorists in positing a new vision of aerial internationalism. But he maintained that the air, as "Free, indivisible, and all-embracing, without barrier or restriction, always self-identical and distributing itself equally over the whole universe, affirms the International principle; and ... we find that it postulates a world-state for its effective functioning" (Burney 1929, 169-70).

Links between internationalism, aviation and a putative world-state were common currency in interwar intellectual circles. Alongside broader efforts to reimagine and re-legislate the nature of territoriality for an aerial age (see Banner 2008), the likes of Winston Churchill, Robert Cecil and others across the political spectrum saw the air as a new dimension of untold military power, and thus foresaw need for an international aerial police force to keep national air forces in check and preserve the peace. Writers like Kipling, Wells and Bertrand Russell likewise offered visions of a future in which world peace was maintained by a world state, whose chief sphere operation would be the air (Partington 2003; Holman 2010; Zaidi 2011). Like others of his ideological persuasion, Burney sought to reconcile the political and scalar contradictions of imperialism and internationalism (Legg 2009) by scheduling the evolution of one into the other, advocating what he called a "philosophy of gradualness" (Burney 1929, 8). With other imperial thinkers of his time, Burney saw a peaceful international order as a long-term project: imperial development should be pursued first, laying the Anglophone, capitalist foundations of a future world order in the technical, economic and cultural structures of Empire (Bell 2007). This was a socio-technical imaginary of world-historical dimensions, featuring an imaginative geography which projected imperial power through a global airspace, delineated as a new sphere of imperial mobility and conquest. As Lord Thomson, the subsequent Labour Air Minister put it, the airship scheme would prove that "the air and the four corners of the earth are ours to command", and Ramsey MacDonald would likewise later predict that "we shall conquer the air as we have conquered the desert and conquered the sea" (quoted in Pirie 2009, 133-4). 


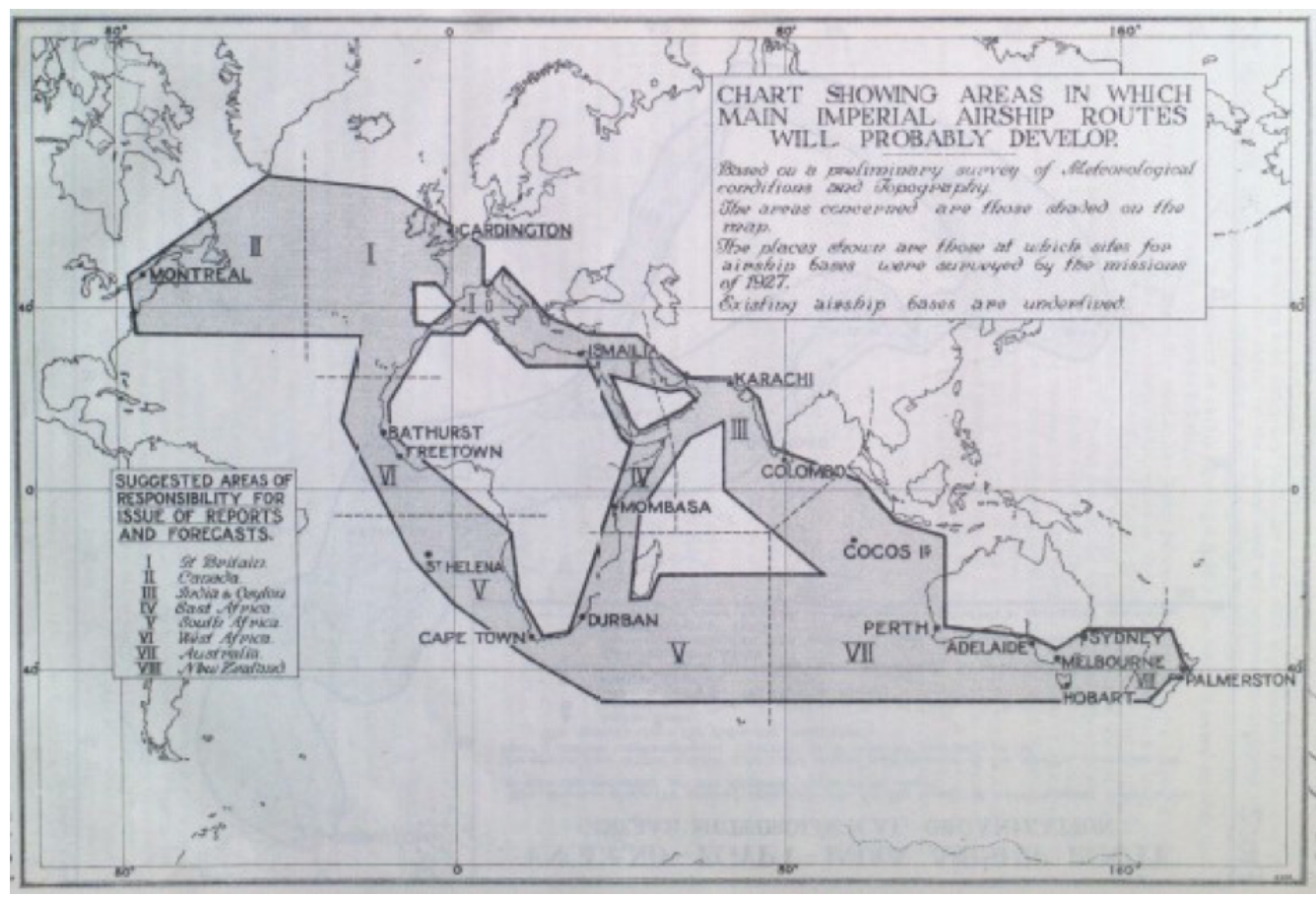

Figure 1. The anticipatory cartography of (probable) imperial airspace. Report of the Conference of Empire Meteorologists, HMSO, 1929

Such parallels were frequently drawn with Britain's earlier command of oceanic space, with airships seemingly representing the natural next step in Britain's conquest of the elements, and thus of the globe. Socio-technical imaginaries are always "bound up with the hard stuff of past achievements", technological systems serving “a doubly deictic function”, pointing back at past achievements and ahead to promising futures (Jasanoff, 2015: 22). For Burney, the airship would eventually become a sea-borne vessel, flexibly able to land on water anywhere, but also able to take advantage of older infrastructures of Britism maritime mobility - the trade winds, a global network of ports. This was a strategy of making future mobilities robust to expected changing geographies of trade, but also of discursively and materially layering airship mobilities on top of a much older set of imperial infrastructures and imaginaries.

Concurrent developments in other emerging aerial powers illustrate what Butler (2001) calls the 'technogeopolitics' of interwar airspace, and the multiple imaginaries which gathered around airship technology. In Germany, Felix Eckener had taken on Count Zeppelin's mantle as the key driver of airship ambitions. The privations of the Versailles treaty, and particularly French concerns about aerial sovereignty, meant state support was muted (or at least surreptitious), and finance was sought from a section of the public concerned with Germany's technical and scientific renewal (Syon 2002). Alliance and support was also sought from other nations, such as 
Spanish partnership to unlock new air routes to South America, foreshadowing later aerial neocolonialism in the region (Cushman 2006), and in the US, where the Navy was busy positioning airships as a key fixture of an imagined climax encounter with Japan. Amidst these imperial, military and commercial projects, airships were also positioned as agents of international cooperation in scientific exploration. This was useful in Germany, where Eckener surmised that "the Entente cannot deny us Germans the right to build an airship for purely scientific purposes" (quoted in Duggan and Meter 2001, 107). European geographical societies identified the airship as a powerful new means of unlocking knowledge of sparsely-explored areas, particularly the polar regions. The Italian-built Norge conducted the first overflight of the North Pole in 1926, under the leadership of the Norwegian Roald Amundsen, in an admixture of intra-Scandinavian technological rivalry and Italian fascist nationalism (Capelotti 1999). The latter was to be reinforced in 1928, when the Italia "circled the Pole, dropped proper flags and a papally-blessed cross, and sang the fascist anthem" (Duggan and Meyer 2001, 121).

In different corners of the British Empire aviation geopolitics called forth different imaginaries too. Early proposals for imperial airshipping had come from the Agent-General of Tasmania in 1921, but while metropolitan aviation boosters focused on the production of airspace which would eventually reach but then stop at New Zealand, Australasian thinkers agonised over competing British and American interests in the Pacific, while theorising the centrality of aviation to the making of a unified "Australasian world" (Henry 2014, 237). In East Africa, imperial imaginaries of all-red routes to the Cape frequently clashed with local settler-colonial imaginaries of aviation in the service of colonial development (McCormack 1989). Back at the metropole, by the mid-1920s Burney had nonetheless become the propagandist in chief of imperial airship development, as well as the chief architect of its technical underpinnings. Circulating his ideas around Parliament and through his networks of engineering and military elites allowed an efficient enrolment of political and technical allies. The Admiralty under Leo Amery foresaw a reserve 'aerial navy' in a commercial fleet and thus supported Burney, and sought to regain control of Britain's airships from the Air Ministry. The latter, meanwhile, were largely defensive, wary of the intrusion of private enterprise into their domain at Cardington in Bedfordshire, home of Britain's modest wartime airship infrastructure. The Labour government which came to power in 1924 were broadly supportive of Burney's plans and sought compromise. Rather than start with six airships, Lord Thomson, the new Air Minister, opted to start with two, and the plan was transformed into an experiment in state versus private 
innovation. The two airships were to be designed separately to the same basic specs, one under Burney, Barnes Wallis, the engineer-novelist Neville Shute and the Vickers Company at Howden in Yorkshire, and one directly under the Air Ministry at Cardington. The project continued under the subsequent Conservative administration, with Labour returning to power in 1929 when trial flights of the two ships - Burney's R-100 and the Ministry's R-101, were getting underway.

\section{The Weight of Expectation}

Imagination rests on expectation, in the form of assumed causal relationships between actions and reactions. In the case of large-scale technical projects like the airship scheme, causal relationships are claimed at a broad scale between technical and social change, or between the public performance of technologies and the spread of favourable opinion among various publics. At a more prosaic level, projects are guided by uncertain and often contested expectations of the performance of machines in future conditions which may be or may not be amenable to precise calculation. This sociology of expectations works through, and produces, various kinds spatiality, as a small number of geographers have recently shown (Milne 2012; Porter and Randalls 2014). In this section I focus on the spaces of performance and experimentation through which expectations of both near-term and long-term airship futures were produced and transformed.

The two airships were from the outset about more than just aviation and empire, but about the public performance of a new role for the state in processes of technical and infrastructural innovation. Despite rivalries between the two teams and the absence of significant information exchange between them, R-101 was developed very much in the public eye, with an active press section in the Air Ministry producing regular celebratory updates on progress. And as soon as that progress would allow, test flights were started which combined technical trial with public spectacle. R-100 was the first to complete a long-distance trial flight, successfully crossing the Atlantic to Quebec in 3 days, prompting spectacular outbursts of imperial pride. The ship spent 12 days moored at Montreal, and it was estimated that 300,000 came to visit it, 70,000 of whom stepped on-board, while Burney busied himself imploring local dignitaries to get behind the scheme with hard cash (Swinfield 2012). Meanwhile, French Canadians deplored "the monster" as an instrument of British repression (quote from Duggan and Meyer 2001, 169). Back in England, R-101 was struggling to keep up, and the success of R-100's transatlantic crossing increased the weight of expectation on R-101's planned inaugural flight to India. Thousands lined the roads around Cardington for the spectacle of the ship leaving its hangar on a still 
autumn morning in October 1929, and around a million were thought to have travelled to see the airship hanging at the mask, many of whom riotously greeted its return from a trial flight: " $\mathrm{A}$ large crowd, including many women, carried away with enthusiasm, broke into the aerodrome and rushed to the mooring tower. They cheered Major Scott [the captain] wildly".

The overlapping of technical trial and public performance was most obvious when two of the contracted test flights of R-101 functioned respectively as the ships' rehearsal for, and participation in, the 1930 Hendon air show. As Adey $(2010,57)$ has shown, air shows in the interwar period were crucial sites for spreading 'air-mindedness', performing new socio-technical relationships, for materialising futures, and for "the projection of the nation into the sky". The air show, with its combination of spectacular aeronautics and behind-the-scenes access to the infrastructures of flight, was a complete sensory apparatus enveloping the spectator in what Adey calls "the environment of the air" (ibid, 60). At Cardington, this kind of sensory apparatus was a joint product of choreographed spectacle and the affective charge of an overjoyed crowd, breaking protocol to charge the mast. At Hendon, R-101 drew on the air show vernacular of the seemingly-reckless stunt, designed to display the masterful union of pilot and machine. The ship performed a steep nose dive over the crowd, pulling up steeply at around 500ft., resulting in some structural damage to the ship, but appearing to delight the thousands of onlookers and members of the press. Some saw it as a dip of the nose to the King, others as an unintentional sign of innate aerodynamic instability. The engineers of R-100 were less than impressed, with Neville Shute later expressing his bemusement at this prioritisation of public spectacle over technical trial and controlled stress-testing (Shute 1954/2009).

The shipping magnate Alan Anderson was likewise sceptical of the value of such performances. Convinced that the age of the airship was about to begin, he wondered to the Air Minister whether, instead of spectacular stunts, it might be better if "one or both of the airships could be over the Bank of England at a fixed time every day or at stated intervals for a period", his view being that the "British public would be more deeply impressed [by that] than they would be by an occasional stunt flight". ${ }^{2}$ Airship passengers weren't expected to be the masses who flocked to interwar air shows. Rather, they were the Empire's elite, like London's financiers, who might be persuaded to buy into the vision of Burney and others of smooth, luxurious conveyance between the financial hubs of the Empire. They would be treated to a "flying hotel", ballroom-dancing after dinner, or surveying the passing scene below from the promenade deck (Figure 2). 


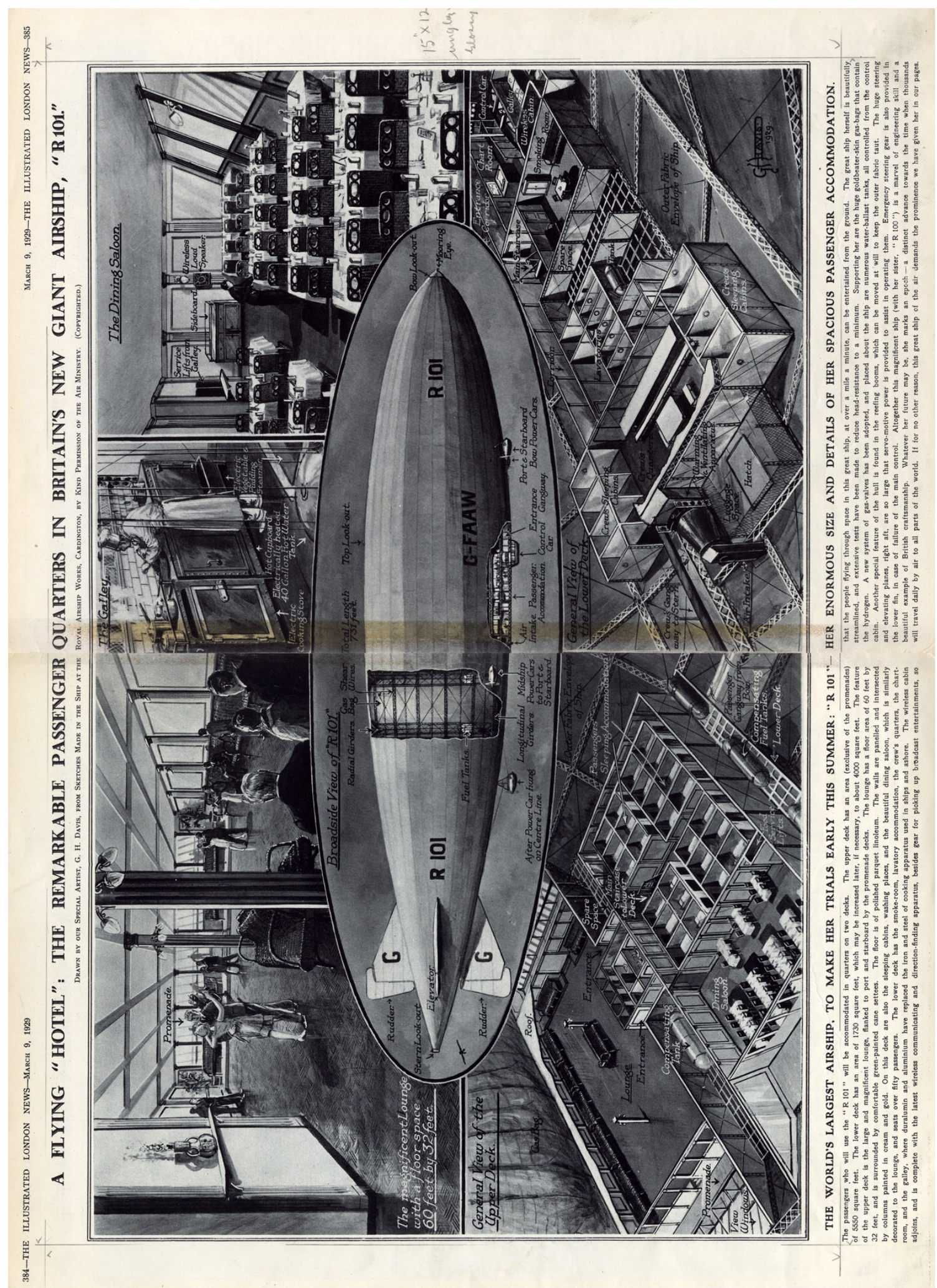

Figure 2. Illustrated London News, 9th March 1929 
Lord Thomson himself participated in the performative engineering of expectations, taking to air on-board one of R-101's trial flights, papers in hand and "prepared for a day's work" - a future "enacted in practice" (Tutton 2017, 485). He reported that "no one who has not had experience of this form of travel can have the least idea of its comfort, smoothness, and restfulness" (see Figure 4). But while public expectations of luxury travel were being busily fashioned, critics of the airship scheme argued that these promises were dramatically ill-founded. One particularly prominent critic was the aptly-named Edward Spanner, a naval architect and novelist whose running commentary on the airship scheme culminated in his 1928 book Gentlemen Prefer Aeroplanes!. Drawing both on his technical expertise and on the gendered politics of 1920s aviation (Millward 2008), Spanner took aim at the efforts of politicians and journalists to assure the public of the safety, stability and comfort or airship travel. While newspapers promised readers that they could soon be doing the "foxtrot in the clouds", Spanner sought to paint a picture of irreducible aerodynamic instability. The logbooks of airships built during World War I highlighted how in certain atmospheric conditions an airship must pitch up or down, compensating for changing weight or gas pressures. While designers promoted the comparable luxury of airship and ocean liner travel, Spanner described a very different elemental geography in diagrams highlighting what the expected angles of tilt would look like in the case of an ocean liner, to illustrate just how unreasonable it would be to expect passengers to tolerate this kind of turbulence. While figures like Burney celebrated the lifting of British imperial maritime culture into the air, Spanner suggested that the relative instability of the atmosphere made the whole exercise impractical, even dangerous: "It must be recognised that the air is an extremely unstable medium through which to make a passage" (Spanner 1928, 33). In a debate at the Institute of Naval Architects he insisted that "he did not see how it would be possible for passengers to move about on the dance floors, about which so much has been heard, without 'storm rails". 3 The ship's chief designer countered that the amount of pitch would be insufficient to spill a cup of tea. In his book Spanner was more dramatic in describing the assemblage "within which people on the move [would be] sustained" (Adey et al. 2012, 171): “Only passengers closely confined in well upholstered quarters, plentifully supplied with handrails and protective devices, can expect to survive a Trans-Atlantic flight in a rigid airship" (ibid, 96). Far from fox-trotting in the clouds, passengers would be lucky to come out of them alive.

The socio-technical imaginary of imperial airshipping featured an imaginative geography of the atmosphere as a smooth space, ready to be traversed, conquered, by imperial technologies, re- 
harnessing the trade winds which had favoured Britain's earlier maritime expansion (Bankoff 2017). Here, however, this imaginary conflicted with understandings of the atmosphere as a much more vibrant, unstable, even violent place, where airships would be vulnerable to a range of perhaps unpredictable physical forces. Accusations circulated that efforts to engineer expectation in support of the dominant imaginary had pushed-out efforts to comprehend the atmosphere differently: "I must point out", wrote one Air Ministry staffer to the Minister, "that Cmdr. Burney in his eagerness to inflame imagination has skated over the very serious Meteorological difficulties involved in his series of demonstration flights".

Technical expectations had to be fashioned of how bits of the ships would respond in different climates, organised around an imaginative geography of climatic excess. A program of climatic experimentation was begun, with different covering fabrics exposed to the Egyptian sun, and new study made of average atmospheric conditions at and around tropical mooring masts. Where information on local climates wasn't available, standardised instruments were despatched from Kew Observatory, and a new comparative climatology of the empire developed, where in the past meteorological and climatological coordination had been minimal (Mahony 2016). Kew figured here as the standard climate - "the known climate of $[\mathrm{Kew}]$...may be taken as the standard of reference when considering the particulars for places overseas" read one report. ${ }^{5}$ Imaginative geographies of tropicality have always rested on an idea of climatic normality 'at home' (Livingstone 2002; Driver 2004), but here this distinctly imperial gesture was explicitly codified in the organised production of climatological knowledge. A particular climatological worry concerned the potential combustibility of petrol engines in tropical atmospheres; a fearful projection of climatic excess informed the replacement of R-101's petrol engines with weightier crude oil motors, the segregation of petrol and tropical climate inscribed in Air Ministry policy. ${ }^{6}$ Divergences in the design of the ships were increasingly seen in climatic terms, competition between the two transforming into meteorological complementarity, with R-100 and R-101 respectively aiding "materially the arrival of long-distance airship routes in both temperate and tropical climates"?

Reporters were treated to demonstrations of the new fuel's safety, with Wing Commander CaveBrown-Cave extinguishing a burning tray of petrol by smothering it with oil. ${ }^{8}$ To take the extra weight, the ship was cut in two and an extra bay inserted, and the gas bags allowed to expand to generate more lift. Signs of the over-inflated bags chafing on the metal framework were met with padding on the sharp edges, and as the date of the craft's maiden voyage to India approached, 
anxiety about the lack of testing of the new configuration in all weather conditions began to take hold. Testing of the load-bearing capacity of the new frame was largely confined to pen-andpaper, and even Burney was starting to express anxiety about the fate of the ships. The publication of his book in 1929 was a highly politicised intervention in the contest of expectations. He described a number of technical drawbacks of the "experimental" craft, perhaps anticipating that failure would irrevocably damage the whole development trajectory, whereas failure under 'experimental' conditions could perhaps be tolerated. The ships under development were cast as "merely preliminary steps in the evolution of a practical commercial vessel", and not themselves resilient enough for commercial regularity under different atmospheric conditions (Burney 1929, 220). The Ministry carefully rebutted the idea that the lack of immediate commercial viability meant that airships in general were non-starters: "We expect that as a direct result of the knowledge now available there will be a great future for airships, not only as a means of making the far corners of the world easily accessible, but also as a means of developing the trade and commerce of the Empire to a degree never before contemplated". 9 key element of that emerging knowledge was a new infrastructure for observing the atmospheric spaces through which the airships would pass, informing new practices of weather prediction which might render the 'unstable medium' of the air safe for passage.

\section{Prediction: charting the air}

The air is a mysterious element, where tremendous and, as yet, incalculable forces are encountered. Scientists can predict the normal consequences of these forces, but not their vagaries; to the latter the only guide is practical experience, acquired painfully, perilously, and often unexpectedly.

- $\quad$ Lord Thomson $(1927,112)$.

Efforts to map and anticipate the atmospheric environment through which airships would venture had a transformative effect on meteorology. During World War I, many aeroplane pilots had been sceptical about the value of meteorology in helping them navigate the atmosphere (Harper 2008). But airships were a different prospect: while aeroplanes work by outrunning gravity, generating lift with speed, airships defeat gravity primarily by working with the atmosphere. The buoyancy of balloons and airships is a product of relationships between the gases inside and the air outside; relationships shaped by temperature, pressure, sunlight, precipitation (McCormack 2009). Changes in temperate and pressure affect the density of the airship's gas in relation to the air around it - especially significant for a ship voyaging from temperate to tropical latitudes - while rainfall or snowfall add weight to the ship, requiring 
compensation in forced changes of pressure or weight, perhaps by jettisoning stored water or, in extreme situations, dumping fuel. The piloting of an interwar airship was therefore a complex process of working with the atmosphere through the physical apparatus of instruments, piloting wheels and body. The bags and hull of R-101 were fitted with a system of valves so that gas could be automatically vented in response to changing atmospheric conditions: "an ingenious adaptation of the principle of fish gills" permitting "the hull envelope to 'breathe.,"10 But changing atmospheric states could also be anticipated as functions of weather. Airship captains generally tried to avoid headwinds and vertical air currents, and to navigate around storms (Roach 1981). But some captains continued to take a gung-ho attitude towards meteorological risk - Neville Shute related how on the R-100's voyage to Canada, as the ship approached a storm:

I was in the control car with [Captain Scott] before we went up for sherry, and heard him make the decision to go through it rather than fly round it; we had ample fuel and there was no occasion to take the ship, already damaged, through this storm ... even with the lesser knowledge of those days, Scott should have known better (Shute 1954/2009, 119).

Airshipping required an appreciation of atmospheric processes on a finer scale than organised meteorology had until that point been able to tackle. This point was driven home by the loss of the USS Shenandoah in a squall line over Ohio in 1925, which was followed by calls for a much denser observational network so that such violent disturbances might be foreseen. Furthermore, the routes of the imperial airship scheme meant that regions of the atmosphere would have to be traversed which until that point had been relatively under-explored. As the Conservative Air Minister put it in his Empire of the Air: "The need was ... to chart the air just as the sea had been charted by generations of hydrographers. Whilst it had taken centuries to chart the seas, we were attempting to chart the air in a few months" (Hoare 1957, 225).

Throughout the 1920s, hastily arranged meteorological services were rolled-out in territories such as British East Africa and British Malaya (Mahony 2016), and new airspace produced through the rapidly evolving practices of aviation meteorology - pilot ballooning, synoptic charting, point-topoint forecasting (Henry 2014). At the metropole an Airship Meteorological Division was set-up under Maurice Giblett, who had worked with the Royal Engineers during the war and subsequently earned a reputation as a reliable Meteorological Office forecaster. He toured prospective airship routes, advising local governments on the kinds of informational 
infrastructure required, and scouting-out atmospheric conditions at potential airship bases.

Giblett's Cardington Division created new geographies of circulating meteorological information, as data started to flow towards the metropole from Malta, Ismailia, Baghdad, Karachi and beyond, places where colonial meteorology had previously been a more avowedly local affair. The first achievement of Giblett's outfit was a synoptic chart stretching from England to India (Figure 3), the first time this atmospheric space had been charted in such detail, although the chart is as eloquent of the geographies of observation as the dynamics of the weather itself. The scattered symbols tell of expanding European networks and forays into colonial territories, and emphasise the largely blank spaces of the Middle East, traversed only by projected pressure contours - a major lacunae and a source of climatological anxiety about the dynamics of the "torrid middle-eastern summer" and its navigational implications (Duggan and Meyer 2001, 132).

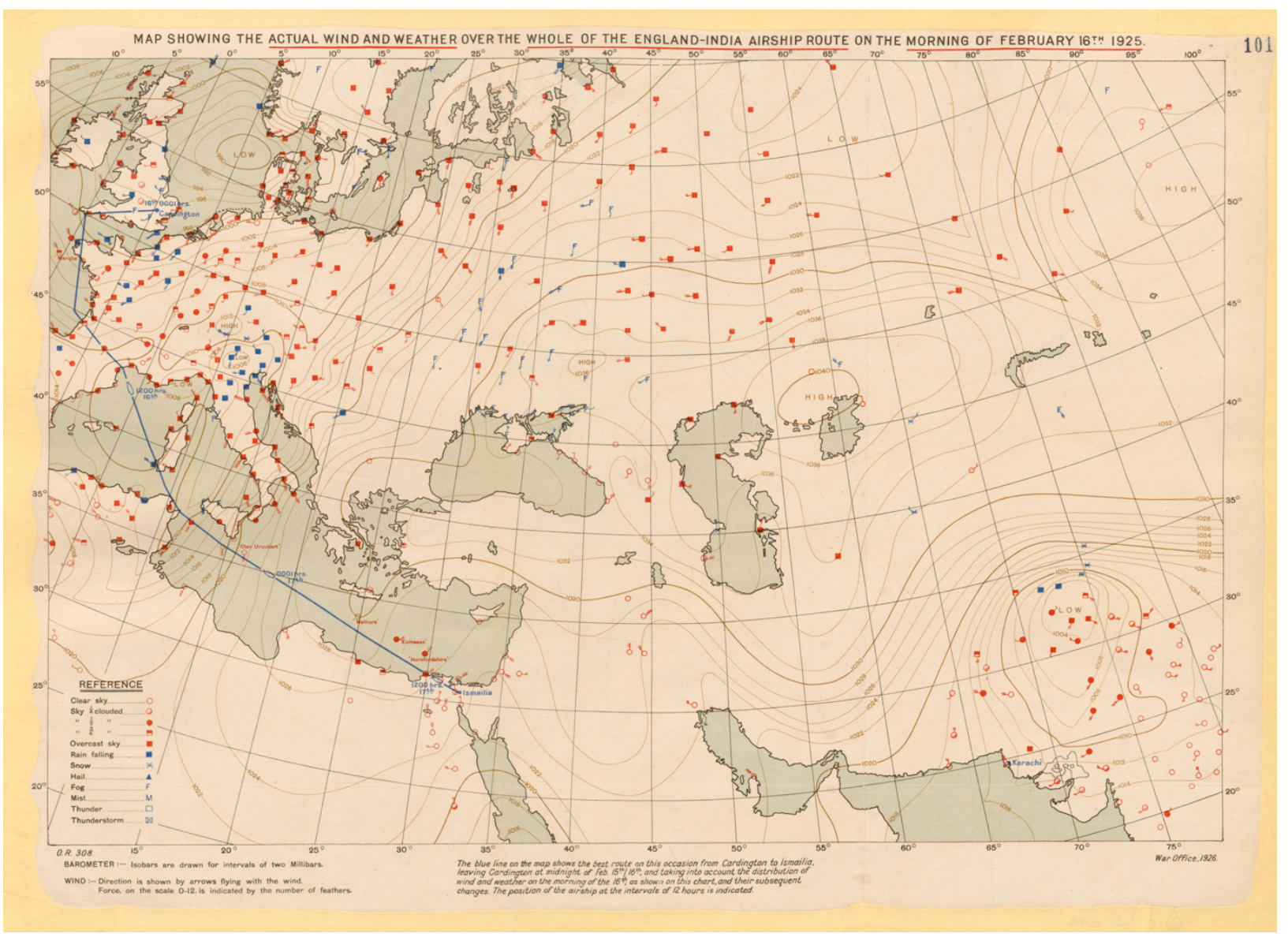

Figure 3. Source: MPI 1/410/6, National Archives 
This striving for new horizontal coverage of the atmosphere was matched by an interest in the vertical structure of the atmosphere on a fine scale. A new granularity was pursued, expressed at Cardington in new spaces and architectures of weather observation. A network of towers bristling with wind-recorders enabled new analysis of the three-dimensional "structure of wind", its patterning in space and time and its interactions with the landscape, on the scale of seconds rather than hours (Giblett 1932). Such knowledge could guide the anticipation of the what McCormack $(2009,33)$ labels, in a Spinozist move, the 'agreement' between aerostatic object and a body of windy air. The cost of suspension in a still parcel of air was the risk of violent displacement when things became more turbulent, and while some worried that such "disturbances are too varied and complex to be known", attempts at mitigation could be made through precise calculation of the forceful effects of gusts on the structure of the ship, through new possibilities of anticipating fine-scale atmospheric movements, and through the bodily responses of the pilots when the "stillness in motion" of steady flight was disrupted by the "sudden, rapid, uncontrolled" movement of a ship thrown into momentary disequilibrium with its atmospheric environment (McCormack 2009, 33, 36).

While for some in this period weather prediction promised atmospheric mastery, the peculiarities of airships' elemental encounters meant that the atmosphere was increasingly comprehended as a lively and perhaps unpredictable environment (cf. Pietruska 2017). The limits of predictability were inscribed in new spaces of meteorological practice, such as a new elevated weather centre which raised meteorologists to the same level as airship pilots on approach to the mast (see Figure 4). The meteorologist could thus visually observe those atmospheric processes which eluded instrumental recording, and the effects of those processes on an approaching ship. The emphasis was on a close interaction of meteorologist and captain, whether in pre-flight conferences where charts were inspected and routes plotted, or, in early flights especially, through the presence of a meteorologist on-board ship. The meteorologist's subjective interpretation of the weather and its predicted evolution was key. Decisions to fly were shaped by these predictions, by the captain's trust in the meteorologist's judgment, and also by more tacit expectations of the performance of ship and crew in different atmospheric conditions. Simulations were conducted to "practise the navigational work involved in taking a ship out from Cardington to an Empire base under the prevailing wind and temperate conditions", ${ }^{2}$ in an anticipatory production of virtual airspace (Budd and Adey 2009) through which changes in the 
weather could be met with changes of route. By late 1930, the virtualities of predicted weather and navigational rehearsal would shape the decision to fly for India.

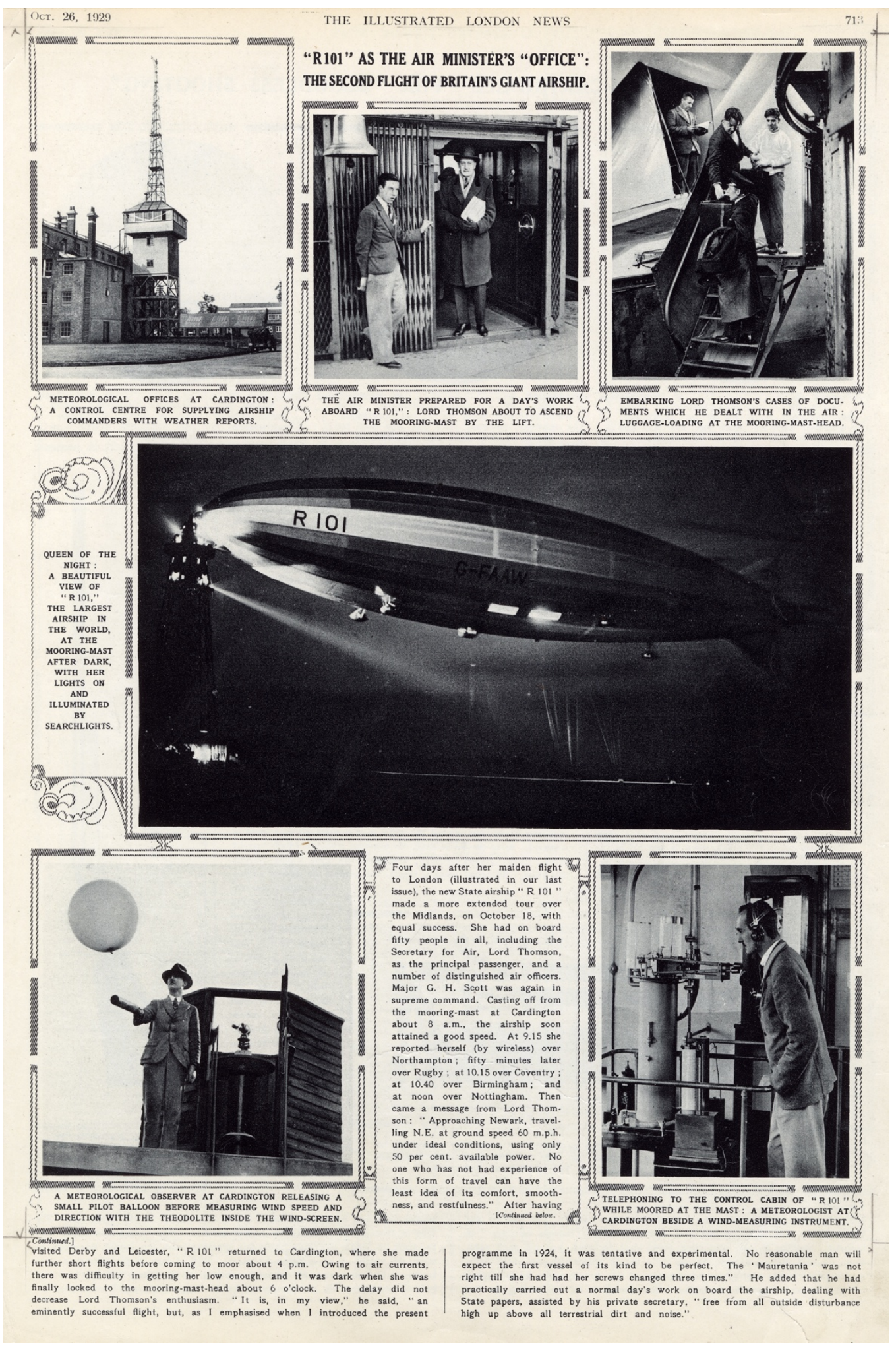

Figure 4. Illustrated London News, 26 October 1929 


\section{The Ends of Futures Past}

Imagination, expectation and prediction collided forcefully on the night of 4 October 1930, the date of R-101's maiden voyage to India. The Labour Party were back in office and Lord Thomson was back at the Air Ministry, his personal investment in the scheme evident in his giving himself the title of 'Lord Thomson of Cardington'. Much speculation surrounded his apparent desire to be the next Viceroy of India - born in Nasik, he had his first involvement in ballooning when attached to the Royal Engineers balloon battalion during the Boer War. Since then he'd proved himself a perceptive military attaché and was seemingly eyeing a career in imperial governance. As Shute put it, "he wished to visit his new empire in the new vehicle of Imperial communications that he had a hand in producing, arriving from the skies in a manner unknown to any previous Viceroy" (Shute 1954/2009, 137).

The return leg would be spectacle too. The Imperial Conference was approaching and Thomson was keen that the return flight be completed before it began. Dominion premiers had "peeped into the future" with a visit to Cardington during the 1926 Imperial Conference, enjoying unique access to the 'Government secrets' of the R-101's construction. ${ }^{13}$ Come 1930, the spectacle of the Air Minister returning safely and speedily from India to chair proceedings would help cement both public and Dominion support. But spectacle was not just planned for the journey's endpoints. Earlier that year the British government had refused a German airship passage over Egypt, to preserve the spectacle of an airship flying over the pyramids for their own craft. Thomson planned a banquet for local dignitaries while at the mast at Ismailia, the ship carrying extra fuel so that guests wouldn't be disturbed by the sound and smells of refuelling. Although he stressed that no risks should be taken on his account, sources agree on the presence of a fevered atmosphere of last-minute engineering to get the ship ready for the voyage of the Viceroy-in-waiting (e.g. Swinfield 2012; Masefield 1982). An airworthiness certificate was hastily granted by the Air Ministry, and with that, R-101 was ready to go.

The weather throughout October $4^{\text {th }}$ was dire, a period of relatively settled weather punctured by a large depression. The $1 \mathrm{pm}$ chart suggested winds of 20-30mph over northern France - not especially dangerous, but conditions at Cardington worsened throughout the afternoon. Whether Giblett himself supported the decision to depart cannot be precisely known. A biography written by his daughter describes the stress he was under before the departure, grappling with the uncertain information at his disposal, issuing a forecast according to orders when perhaps no 
reliable forecast was really possible. Despite the meteorological uncertainty, Giblett was apparently confident of the risk-aversion of his superiors, his last words to his family before he set off for the aerodrome being "Don't worry, we won't be going" (Holmes 2008, 285). The passengers, a number of Air Ministry officials and experts who'd been involved in the scheme, climbed aboard, followed by an unexpected number of cases of wine and a fine carpet for the Egyptian banquet, as well as a gifted keg of beer, festooned with British and Indian flags. The ship set off in the early evening in the drizzling rain, to the strains of a brass band playing God Save the King.

A new forecast wasn't available until just after 8pm, which suggested much stronger winds of 40$50 \mathrm{mph}$. This turned out to be much closer to the truth, and once over northern France the ship struggled against strong headwinds and driving rain. Shortly after the 2am change of watch, and before the new crew could get a feel for conditions, it seems a violent down draft caused the ship to go into a dive, opening a tear in the covering fabric, causing hydrogen to escape, thus triggering a second, fatal dive into a hillside, upon which the ship burst into flames. All but six of the 52 on-board were killed, including Thomson, his valet and many of his advisors, and Maurice Giblett.

The victims of R-101 were lauded in the press as fallen heroes, sacrificed to the imperial cause, and memorialised with services at Westminster Abbey and St Paul's cathedral - the 'Empire's Valhalla' as the Pathé Gazette described it (Pirie 2009, 135). The atmosphere of October $4^{\text {th }}$, both meteorological and affective, became a matter of official inquest as experts and witnesses to a Court of Inquiry reconstructed the ship's troubled technical development, what had been known about the weather, and how the decision to fly had been made. In addition to a combination of bad weather and structural faults, some caused by the alterations made to adapt the ship to tropical climates, the Inquiry's final report honed in on "the atmosphere in which the decision to start was taken", offering an almost sociological reading of the economy of expectations which shaped that decision (cf. Borup et al. 2006). The report describes an affective atmosphere formed by a complex web of expectations: the knowledge that the flight was experimental, and that its elemental encounters could not be wholly predicted with "theoretic calculations"; the elongated and frustrating period of waiting for the ship to be ready, which had been neither "anticipated or calculated"; the awareness that funds for further airship development, for which plans existed, were contingent on the outcome of this flight; the relative 
success of R-100's voyage to Canada; "the personality of the Secretary of State"; and the "hopes" of the "resolute men who believed wholeheartedly in the policy". As for the weather, it was considered "doubtful if a start would have been made had wind speeds been accurately forecast 12 hours in advance". The Inquiry didn't blame any individual for the failings which apparently caused the crash. But it did state that it was "impossible to avoid the conclusion that the R-101 would not have started for India on the evening of October 4th if it had not been that matters of public policy were considered as making it highly desirable that she should do so."14

\section{Conclusion}

In the end, no British airship ever made it to the tropics. The scheme was halted, R-100 was steamrollered and sold for scrap - some of which, it is rumoured, ended up in the Hindenburg, whose fiery end in 1937 brought the interwar passenger airship age quite conclusively to an end. In Germany, re-purposed airships took on sentinel roles at the militarised border, with new electronic surveillance technologies employed to pick up non-German radio broadcasts, before the technology was abandoned by the state. The airship soon reappeared however in the retrofuturism of steampunk (Davidson 2012), an aesthetic that can be traced to Michael Moorcock's 1971 novel $W$ arlord of the Air which projected British imperial airshipping forward to a counterfactual 1973. The elemental encounters of interwar airshipping informed new research into fine-scale atmospheric dynamics, with Cardington becoming a centre of 'boundary layer' meteorology, while the history of R-101 has become a touchstone for those critical of political actors who would imagine and seek to actualise new socio-technical orders through state-led infrastructural transformation (e.g. Myddleton 2007). However, airships have reappeared in more recent encounters of state and atmosphere. One of the UK's chief climate change diplomats has frequently promoted the technology as a solution to the environmental impacts of jet aviation and global freight transport (also Carey 2012), while dirigibles have also appeared on the contested horizon of 'Brexit', as a possible solution to the fraught question of the Irish border. Reprising their later use in Germany, they've been envisaged as an alternative to a 'hard border' on the ground by being ever-present in the air, monitoring the comings and goings of trade in partnership with a fleet of drones. Once again, in political imaginaries of a future Britain, forged in a time of national anxiety, the airship floats into a view as a socio-technical solution to a fraying territorial order. 
Thinking imagination, expectation and prediction together provides a fruitful way forward for reconstructing historical geographies of the future. Building on a developing literature on the geographies of anticipation and expectation, I've suggested that we interrogate both the material and imaginative geographies brought into being by these modes or practices of futuring. I've focused on imaginative and material encounters with the atmosphere - a space where imperial futures were projected, climatic anxieties negotiated, and the chaos of turbulent matter fatefully reckoned with by meteorological minds and piloting bodies. These practices of futuring work on and through present geographies (Anderson 2010) - whether the changing spaces of meteorological knowledge production, the overlapping spaces of public spectacle and performance-testing, or the circuits of elite knowledge, influence and alliance through which a socio-technical imaginary of imperial airshipping gained performative power.

The analysis presented above joins with new materialist scholarship in offering the atmosphere as a vital space of critical geographic inquiry. But it contends that geographers attend more closely to the socio-technical work involved in making twentieth century atmospheres, and suggests, following Barry (2015), that greater analytical attention to societies' anointed spokespeople for non-human matter (such as meteorologists or engineers), and the politics of their expertise, can reveal more about how social relationships are mediated through the materiality of technical innovation and elemental encounter. The framework introduced in this article can also help us dig deeper into technologies around which new spatial relationships are being assembled, to interrogate their loading with imaginative projections and weighty expectations, and thus to identify points at which such innovations may be contested or redirected. More broadly, we need to connect work on the place of anticipation, prediction and expectation in the organisation of social life with new attention to the place of imagination and imaginative geographies in the promises and politics of socio-technical transformation. In so doing, geographers will find much that is new to say about 'the future' as an object around which multifarious projects of empire-building and world-making are organised.

\section{References}

Adams-Hutcheson, G. 2017. Farming in the troposphere: drawing together affective atmospheres and elemental geographies. Social \& Cultural Geography, doi: 10.1080/14649365.2017.1406982.

Adey, P. 2010. Aerial Life: Spaces, Mobilities, Affects. Oxford: Wiley-Blackwell. 
2015. Air's affinities: Geopolitics, chemical affect and the force of the elemental. Dialogues in Human Geography, 5(1):54-75.

Adey, P. et al. 2012. Profiling the passenger: mobilities, identities, embodiments. cultural geographies, 19(2):69-193.

Adey, P. et al., eds. 2013. From Above: War, Violence and Verticality. London: Hurst.

Amoore, L. 2009. 'Lines of sight: on the visualization of unknown futures', Citizenship Studies, 13(1):17-30.

Anderson, B. 2010. 'Preemption, precaution, preparedness: Anticipatory action and future geographies', Progress in Human Geography, 34(6):777-798.

Anderson, K. 2005. Predicting the Weather. Chicago, IL: University of Chicago Press.

Andersson, J. 2012. 'The great future debate and the struggle for the world', American Historical Review, 117(5):1411-1430.

Augé, M. 2014. The Future. London: Verso.

Baker, Z. (forthcoming) 'Meteorological Frontiers: Climate Knowledge, the West, and U.S. Statecraft, 1800-1850’, Social Science History.

Baldwin, A. 2016. 'Premediation and white affect: Climate change and migration in critical perspective', Transactions of the Institute of British Geographers, 41:78-90.

Bankoff, G. 2017. 'Aeolian empires: The influence of winds and currents on European maritime expansion in the days of sail', Environment and History, 23(2):163-196.

Banner, S. (2008) Who owns the sky? The struggle to control airspace from the Wright brothers on. Cambridge, MA: Harvard University Press.

Barry, A. 2015. 'Thermodynamics, matter, politics', Distinktion: Scandinavian Journal of Social Theory 16(1):1-16.

Bell, D. 2007. The idea of greater Britain: empire and the future of world order, 1860-1900. Princeton, NJ: Princeton University Press.

Borup, M. et al. 2006. 'The sociology of expectations in science and technology', Tecbnology Analysis \& Strategic Management, 18:285-298.

Bowles, G.F.S. 1926. The Strength of England. London: Methuen.

Braun, B. 2015. 'Futures: Imagining Socioecological Transformation: An Introduction', Annals of the Association of American Geographers, 105(2):239-243.

Budd, L. and Adey, P. (2009) 'The software-simulated airworld: Anticipatory code and affective aeromobilities', Environment and Planning A, 41(6), pp.

Burney, C.D. 1929. The World, the Air and the Future. London: A.A. Knopf.

Butler, D.L. 2001. 'Technogeopolitics and the struggle for control of world air routes, 19101928', Political Geography, 20(5):635-658.

Capelotti, P.J. 1999. By airship to the North Pole : an archaeology of human exploration. New Brunswick, 
NJ: Rutgers University Press.

Carroll, S. 2015. An Empire of Air and Water: Uncolonizable Space in the British Imagination, 1750-1850. Philadelphia, PA: University of Pennsylvania Press.

Collard, R.-C., Dempsey, J. and Sundberg, J. 2015. 'A Manifesto for Abundant Futures', Annals of the Association of American Geographers, 105(2):322-330.

Cushman, G.T. 2006. 'The Struggle over Airways in the Americas, 1919-1945: Atmospheric science, aviation technology, and neocolonialism', in Fleming, J. R., Janković, V., and Coen, D. R. (eds) Intimate Universality: Local and Global Themes in the History of Weather and Climate. Sagamore Beach, MA: Science History Publications, 175-222.

Davidson, R. 2012. 'Mad scientists, airships and class: the politics of Steampunk', Overland, June.

Davison, P. 2015. 'The R.101 story: a review based on primary source material and first hand accounts', Journal of Aeronatical History, 2:43-167.

Derickson, K.D. and MacKinnon, D. 2015. 'Toward an Interim Politics of Resourcefulness for the Anthropocene', Annals of the Association of American Geographers, 105(2):304-312.

Dressler, W.H. 2017. 'Contesting moral capital in the economy of expectations of an extractive frontier', Annals of the American Association of Geographers, 107(3), 647-665.

Driver, F. 2004. 'Imagining the tropics: Views and visions of the tropical world', Singapore Journal of Tropical Geography, 25(1):1-17.

Duggan, J. and Meyer, H.C. 2001. Airships in International Affairs, 1890-1940. Basingstoke: Palgrave.

Engelmann, S. 2015. 'Toward a poetics of air: sequencing and surfacing breath', Transactions of the Institute of British Geographers, 40(3):430-444.

Epstein, K. C. (2010) 'Imperial Airs: Leo Amery, Air Power and Empire, 1873-1945', The Journal of Imperial and Commonwealth History, 38(4), pp. 571-598.

Eshun, K. 2003. 'Further Considerations of Afrofuturism', CR: The New Centennial Review, 3(2):287-302.

Freedman, A. 2004. 'Zeppelin Fictions and the British Home Front', Journal of Modern Literature, 27(3):47-62.

Gilbert, D. and Driver, F. 2000. 'Capital and Empire: Geographies of Imperial London', GeoJournal, 51:23-32.

Gilbert, D. and Lambert, D. 2010. 'Counterfactual geographies: Worlds that might have been', Journal of Historical Geography, 36(3):245-252.

de Goede, M. and Randalls, S. 2009. 'Precaution, preemption: arts and technologies of the actionable future', Society and Space, 27(5):859-878.

Goswami, M. et al. 2012. 'Imaginary Futures and Colonial Internationalisms', American Historical Review,117(5):1461-1485.

Gregory, D. 2011. 'From a View to a Kill', Theory, Culture \& Society, 28(7-8):188-215. 
Harper, K. 2008. Weather by the Numbers. Cambridge, MA: MIT Press.

Heffernan, M. 1999. 'Historical geographies of the future: three perspectives from France', in Livingstone, D. N. and Withers, C. W. J. (eds) Geography and Enlightenment. Chicago, IL: University of Chicago Press, pp.125-164.

Henry, M. 2014. 'Australasian airspace: meteorology, and the practical geopolitics of Australasian airspace, 1935-1940', in Beattie, J., O’Gorman, E., and Henry, M. (eds) Climate, Science, and Colonization. Basingstoke: Palgrave, pp.233-250.

Hilgartner, S. 2015. 'Capturing the Imaginary: Vanguards, Visions, and the Synthetic Biology Revolution.', in Hilgartner, S., Miller, C. A., and Hagendijk, R. (eds) Science \& Democracy. London: Routledge, pp.33-55.

Hoare, S.S. 1957. Empire of the Air: The Advent of the Air Age, 1922-1929. London: Collins.

Hodder, J., Legg, S. and Heffernan, M. 2015. 'Introduction: Historical geographies of internationalism, 1900-1950', Political Geography 49:1-6.

Holman, B. 2010. 'World Police for World Peace: British Internationalism and the Threat of a Knock-out Blow from the Air, 1919-1945', War in History, 17(3):313-332.

Jameson, F. 2005. Archaeologies of the future. London: Verso.

Jasanoff, S. ed. 2004. States of Knowledge. London: Routledge.

2015. 'Future imperfect: Science, technology, and the imaginations of modernity', in Jasanoff, S. and Kim, S.-H. (eds) Dreamscapes of Modernity: Sociotechnical Imaginaries and the Fabrication of Power. Chicago, IL: University of Chicago Press, pp.1-33.

Jasanoff, S., \& Kim, S.-H. 2009. Containing the Atom: Sociotechnical Imaginaries and Nuclear Power in the United States and South Korea. Minerva, 47(2):119-146.

Klinke, I. (2017) Cryptic concrete. London: Wiley.

Koselleck, R. 2004. Futures Past: On the semantics of historical time. New York, NY: Columbia University Press.

Krige, J. and Wang, J. 2015. 'Nation, Knowledge, and Imagined Futures: Science, Technology, and Nation-Building, Post-1945', History and Technology. Routledge, 31(3):171-179.

Kulikowski, M. 2016. 'Fantasy Flights: Technology, Politics and the Soviet Airship Programme 1930-1938', Icon, 21:66-80.

Lakoff, A. 2015. 'Global health security and the pathogenic imaginary'. In S. Jasanoff \& S.-H. Kim (Eds.), Dreamscapes of Modernity. Chicago: University of Chicago Press, pp.300-320.

Latour, B. and Woolgar, S. 1979. Laboratory Life: The construction of scientific facts. Princeton, NJ: Princeton University Press.

Lave, R. 2015. 'The future of environmental expertise', Annals of the Association of American Geographers, 105(2):1-9.

Legg, S. 2009. Of scales, networks and assemblages: The League of Nations apparatus and the scalar sovereignty of the government of India. Transactions of the Institute of British Geographers, 34(2):234-253. 
Lehman, J. 2014. 'Expecting the sea: The nature of uncertainty on Sri Lanka's East coast', Geoforum, 52:245-256.

Livingstone, D.N. 2002. 'Race, space and moral climatology: notes toward a genealogy', Journal of Historical Geography, 28(2):159-180.

— 2003 Putting Science in its Place. Chicago, IL: University of Chicago Press.

Mahony, M. 2016. 'For an empire of "all types of climate": meteorology as an imperial science', Journal of Historical Geography, 51:29-39.

Masefield, P. G. 1982. To ride the storm: the story of the airship R.101. London: Kimber.

McCormack, D.P. 2008. 'Engineering affective atmospheres: On the moving geographies of the 1897 Andree expedition', Cultural Geographies, 15:413-430.

- 2009. 'Aerostatic spacing: On things becoming lighter than air', Transactions of the Institute of British Geographers, 34(1):25-41.

2018. Atmospheric things. Durham, NC: Duke University Press.

McCormack, R. L. (1989) 'Imperialism, air transport and colonial development: Kenya, 1920-46', The Journal of Imperial and Commonwealth History. 17:374-395.

Milne, R. J. 2012. 'Pharmaceutical prospects: Biopharming and the geography of technological expectations', Social Studies of Science, 42(2):290-306.

Myddelton, D. R. 2007. They Meant Well: Government Project Disasters. London: Institute of Economic Affairs.

Naylor, S. 2010. Regionalizing Science. Abingdon: Taylor \& Francis.

O'Lear, S. 2016. Climate science and slow violence: A view from political geography and STS on mobilizing technoscientific ontologies of climate change. Political Geography, 52:4-13.

Palmer, J. 2014. Past remarkable: Using life stories to trace alternative futures. Futures, 64:29-37.

Partington, J.S. 2003. 'H.G. Wells and the World State: A Liberal Cosmopolitan in a Totalitarian Age', International Relations, 17(2):233-246.

Pfotenhauer, S. and Jasanoff, S. 2017. 'Panacea or diagnosis? Imaginaries of innovation and the "MIT model" in three political cultures', Social Studies of Science, in press.

Pietruska, J.L. 2017. Looking Forward: Prediction and Uncertainty in Modern America. Chicago, IL: University of Chicago Press.

Pirie, G. 2009. Air Empire: British Imperial Civil Aviation, 1919-39. Manchester University Press.

Rickards, L. et al. 2014. 'Opening and closing the future: climate change, adaptation, and scenario planning', Environment and Planning C: Government and Policy, 32(4):587-602.

Shaw, I. G. R. 2016. 'Scorched Atmospheres: The Violent Geographies of the Vietnam War and the Rise of Drone Warfare', Annals of the Association of American Geographers, 106(3):688-704.

Shute, N. 1954/2009. Slide rule. London: Vintage Classics. 
Spanner, E.F. 1928. Gentlemen Prefer Aeroplanes! London

Swinfield, J. 2012. Airship: Design, Development and Disaster. London: Conway.

Syon, G. de 2002. Zeppelin! Germany and the airship, 1900-1939. Baltimore, MD: JHU Press.

Taddei, R. (2013) 'Anthropologies of the future: on the social performativity of (climate) forecasts', in Kopnina, H. and Shoreman-Ouimet, E. (eds) Environmental Anthropology: Future Directions. London: Routledge, pp. 244-263.

Taylor, C. 2002. 'Modern Social Imaginaries', Public Culture, 14(1):91-124.

Thomson, C.B.B. 1927. Air Facts and Problems. London: John Murray.

Tutton, R. 2016. 'Wicked futures: meaning, matter and the sociology of the future', The Sociological Review.

Whitehead, M. 2011. State, Science and the Skies. Oxford: Wiley-Blackwell.

Yaszek, L. 2006. 'Afrofuturism, science fiction, and the history of the future', Socialism and Democracy, 20(3), pp. 41-60.

Zaidi, W.H. 2011. “'Aviation Will Either Destroy or Save Our Civilization”: Proposals for the International Control of Aviation, 1920--45', Journal of Contemporary History, 46(1):150-178.

\section{Acknowledgements}

My thanks to the editor and three anonymous reviewers whose comments contributed greatly to the improvement of the manuscript. The development of the ideas in this paper owes much to colleagues in the Cultural \& Historical Geography group at the University of Nottingham, particularly to Steve Legg and his regular despatches from the India Office archives. Thanks too to the conference and seminar audiences at the RGS-IBG, the London Group of Historical Geographers, National University of Singapore, the Hong Kong Maritime Museum and Anticipation-2017 who heard this paper in various iterations and contributed hugely to its development. The support of a British Academy Postdoctoral Fellowship is gratefully acknowledged.

\section{Biography}

Martin Mahony is a Lecturer in Human Geography in the School of Environmental Sciences, University of East Anglia, and a member of the Science, Society and Sustainability (3S) Research Group. Email: m.mahony@,uea.ac.uk. His research interests include climate change politics and the histories and geographies of atmospheric science and technology. 


\section{Notes}

1 'Flying Hotel', Daily Mail, 15 October 1929.

2 Samuel Hoare, Memorandum on meeting with Alan Anderson, AIR 5/996, National Archives, Kew [hereafter

'NA']

3 'State Airship Policy - Particulars of the R101', The Times, 31 March 1928.

${ }^{4}$ Anonymous memo to Secretary of State for Air, AIR 5/1059, NA.

5 'Selection of airship bases: preliminary report on Mauritius', p1. National Meteorological Library and Archive, Exeter [hereafter NMLA].

${ }^{6}$ See the discussion in in AIR 5/1060, NA.

7 'The State Airship', The Times, 27 July 1928

8 'State Airship', The Times, 24 August 1928.

9 'Great care with R-101', Daily Telegraph, 11 October 1929.

10 'The State Airship', The Times, 27 July 1928

11 'Factors of safety for airships', AIR 5/1018, NA

12 'State Airship', The Times, 24 August 1928.

13 'Great Liner of the Air', Dundee Evening Telegraph, 18 November 1926.

14 'Report of the R-101 Inquiry', p.95-6. HMSO, 1931. 